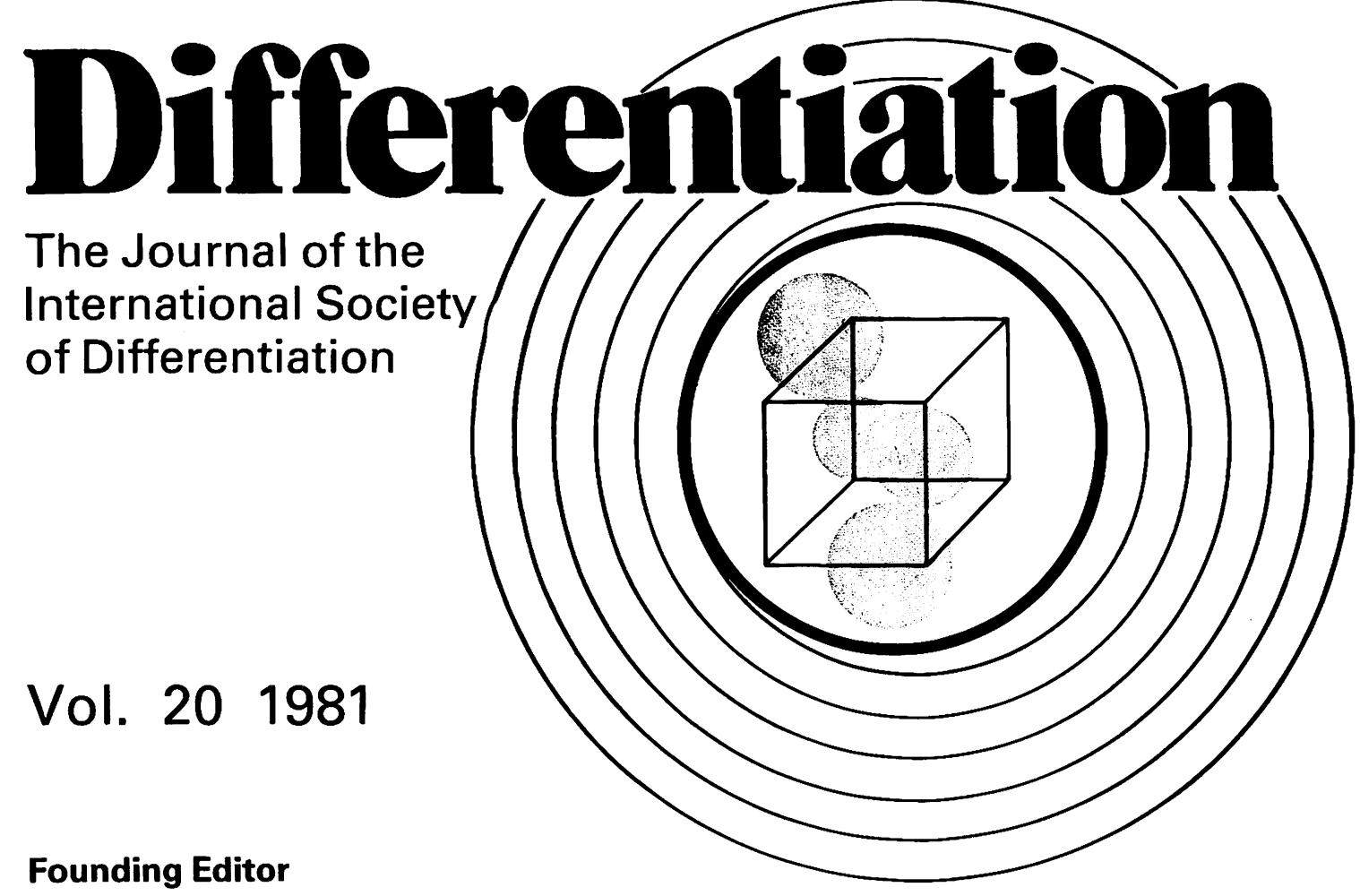

Dimitri Viza (Paris)

\section{Editor-in-Chief}

W. W. Franke (Heidelberg)

\section{Regional Editors}

K. Illmensee (Geneva)

G. B. Pierce (Denver)

\section{Editorial Board}

R. Auerbach (Madison)

J. T. Bonner (Princeton)

J. Brachet (Rhode-St. Genèse)

M. A. DiBerardino (Philadelphia)

L. Du Pasquier (Basel)

G. Giudice (Palermo)

H. Grunz (Essen)

B. Hogan (London)

H. Holtzer (Philadelphia)

Ph. Jeanteur (Montpellier)

H. R. Kobel (Geneva)

L. G. Lajtha (Manchester)
G. V. Lopashov (Moscow)

P. D. MacLean (Bethesda)

L. Margulis (Boston)

C. L. Markert (New Haven)

R. G. McKinnell (St. Paul, Minn.)

F. Meins, Jr. (Basel)

A. Monroy (Naples)

G. J. V. Nossal (Victoria)

S. Ohno (Duarte)

R. M. Pratt (Research Triangle Park)

T. Puck (Denver)

M. Ricci (Firenze)

M. Rodbell (Bethesda)

C. Rosenfeld (Villejuif)

A. Ruthmann (Bochum)

T. Sachs (Jerusalem)

K. Sander (Freiburg)

M. Schachner (Heidelberg)

H. Slavkin (Los Angeles)

M. Sussman (Pittsburgh)

D. Tarin (Oxford)

S. Toivonen (Helsinki)

T. Yamada (Epalinges)

K. Yamana (Fukuoka) 
Abe, S.-I.: Meiosis of Primary Spermatocytes and Early Spermiogenesis in the Resultant Spermatids in Newt, Cynops pyrrhogaster in vitro 65

Adams, D. S., Noonan, D., Jeffery, W. R.: Stored Messenger Ribonucleoprotein Particles in Differentiated Sclerotia of Physarum polycephalum 177

Allen, T. D., see Kinn, S. R. 168

Benedusi, P., see Colombo, R., et al. 45

Bourin, M. C., see Delescluse, C., et al. 87

Bringas, P., Jr., see Cummings, E. G., et al. 1

Carre, D., see Counis, M. F., et al. 188

Caselitz, J., see Osborn, M., et al. 196

Chaudun, E., see Counis, M. F., et al. 188

Colombo, R., Benedusi, P., Valle, G.: Actin in Xenopus Development: Indirect Immunofluorescence Study of Actin Localization 45

Coukell, M. B.: Apparent Positive Cooperativity at a Surface cAMP Receptor in Dictyostelium 29

Counis, M. F., David, J. C., Chaudun, E., Carre, D.: DNA Polymerase, DNA Ligase, and Thymidine Kinase Activity in Chicken Lens, Related to DNA X-Ray Lesion Repair 188

Cramp, W. A., see Harris, G., et al. 92

Cummings, E. G., Bringas, P., Jr., Grodin, M. S., Slavkin, H. C.: Epithelial-Directed Mesenchyme Differentiation in vitro. Model of Murine Odontoblast Differentiation Mediated by Quail Epithelia 1

Custer, R. P., see Schaefer, F. V., et al. 260

David, C. N., see Sternfeld, J. 10

David, J. C., see Counis, M. F., et al. 188

Delescluse, C., Bourin, M. C., Fürstenberger, G., Marks, F. Pruniéras, M.: Differentiation Modulates the Response of Guinea Pig Epidermal Keratinocytes to the Stimulation of DNA Synthesis by TPA 87

Denk, H., see Krepler, R., et al. 242

Duksin, D., see Webb, C. G. 81

Duprat, A. M., see Gualandris, L.

Eguchi, G., see Tsonis, P. A. 52

Engel, W., Klemme, B., Schmid, M.: H-Y Antigen and SexDetermination in Turtles 152

Engel, W., see Epplen, J. T., et al. 124

Engel, W., see Ü̧̧er, U. 162

Engel, W., see Zenzes, M. T. 157

Engelbrecht, I., see Franke, W. W., et al. 217

Epplen, J. T., Kunz, B., Wieczorek-Engelken, G., Engel, W., Schmidtke, J.: Cyclic AMP Phosphodiesterase in Leydig Cell Preparations of the Rat Testis 124

Fischer-Defoy, D., Hausmann, K.: Microtubules, Microfilaments, and Membranes in Phagocytosis: Structure and Function of the Oral Apparatus of the Ciliate Climacostomum virens 141

Franke, W. W., Schmid, E., Grund, C., Müller, H., Engelbrecht, I., Moll, R., Stadler, J., Jarasch, E.-D.: Antibodies to High Molecular Weight Polypeptides of Desmosomes: Specific Localization of a Class of Junctional Proteins in Cells and Tissues 217

Franke, W. W., see Jackson, B. W., et al. 203

Franke, W. W., see Krepler, R., et al. 242

Franke, W. W., see Williams, M. A., et al. 36

Fürstenberger, G., see Delescluse, C., et al. 87

Gasc, J.-M., Sar, M.: Appearence of LH-Immunoreactive Cells in the Rathke's Pouch of the Chicken Embryo 77

Geltosky, J., see Lam, T. Y., et al. 22

Grodin, M. S., see Cummings, E. G., et al. 1

Grund, C., see Franke, W. W., et al. 217
Grund, C., see Jackson, B. W., et al. 203

Gualandris, L., Duprat, A. M.: A Rapid Experimental Method to Study Primary Embryonic Induction 270

Hames, B. D., see Madley, I. C., et al. 278

Harris, G., Cramp, W. A., Olsen, I.: The Acute Effects of lonizing Radiation on DNA Synthesis and the Development of Antibody-Producing Cells 92

Hausmann, K., see Fischer-Defoy, D. 141

Herries, D. G., see Madley, I. C., et al. 278

Hoperskaya, O. A.: Induction - The Main Principle of Melanogenesis in Early Development 104

Illmensee, K., see Jackson, B. W., et al. 203

Ishikawa, M., see Kubo, M. 131

Jackson, B. W., Grund, C., Winter, S., Franke, W. W., IIImensee, K.: Formation of Cytoskeletal Elements During Mouse Embryogenesis. II. Epithelial Differentiation and Intermediate-Sized Filaments in Early Postimplantation Embryos 203

Jarasch, E.-D., see Franke, W. W., et al. 217

Jeffery, W. R., see Adams, D. S., et al. 177

Kinn, S. R., Allen, T. D.: Conversion of Blebs to Microvilli: Cell Surface Reorganisation After Trypsin 168

Klemme, B., see Engel, W., et al. 152

Krepler, R., Denk, H., Weirich, E., Schmid, E., Franke, W. W.: Keratin-Like Proteins in Normal and Neoplastic Cells of Human and Rat Mammary Gland as Revealed by Immunofluorescence Microscopy 242

Kubo, M., Ishikawa, M.: Organization of the Acrosome and Helical Structures in Sperm of the Aplysiid, Aplysia kurodai (Gastropoda, Opisthobranchia) 131

Kunz, B., see Epplen, J. T., et al. 124

Lam, T. Y., Pickering, G., Geltosky, J., Siu, C. H.: Differential Cell Cohesiveness Expressed by Prespore and Prestalk Cells of Dictyostelium discoideum 22

Liquori, A. M., Monroy, A., Parisi, E., Tripiciano, A.: A Theoretical Equation for Diauxic Growth and Its Application to the Kinetics of the Early Development of the Sea Urchin Embryo 174

Madley, I. C., Herries, D. G., Hames, B. D.: Common CellSurface Receptors for Discoidin I and Discoidin II in Dictyostelium discoideum 278

Marks, F., see Delescluse, C., et al. 87

McMahon, D., see West, C. M. 61

Moll, R., see Franke, W. W., et al. 217

Monroy, A., see Liquori, A. M., et al. 174

Müller, H., see Franke, W. W., et al. 217

Müller, U., Urban, E.: An Oocyte-Specific Antigen and Its Possible Role in the Organization of the Ovarian Follicle of the Rat 274

Nardi, J. B.: Epithelial Invagination: Adhesive Properties of Cells Can Govern Position and Directionality of Epithelial Folding 97

Noonan, D., see Adams, D. S. 177

Olsen, I., see Harris, G., et al. 92

Osborn, M., Caselitz, J., Weber, K.: Heterogeneity of Intermediate Filament Expression in Vascular Smooth Muscle: A Gradient in Desmin Positive Cells from the Rat Aortic Arch to the Level of the Arteria lliaca Communis 196

Parisi, E., see Liquori, A. M., et al. 174

Pickering, G., see Lam, T. Y., et al. 22 
Price, J. E., Tarin, D.: Lectin Agglutinability of Mammary Tumours with Differing Metastatic Colonisation Potentials 264

Pruniéras, M., see Delescluse, C., et al. 87

Ptytycz, B.: Ontogeny of Transplantation Immunity in the Common Frog, Rana temporaria L. 71

Sar, M., see Gasc, J.-M. 77

Schaefer, F. V., Custer, R. P., Sorof, S.: Enhancement of Squamous Cell Development in Cultured Skin by Cyclic Adenine Nucleotide and Prostaglandins 260

Schmid, E., see Krepler, R., et al. 242

Schmid, M., see Engel, W., et al. 152

Schmid, E., see Franke, W. W., et al. 217

Schmidtke, J., see Epplen, J. T., et al. 124

Sieber, F., see Sieber-Blum, M. 117

Sieber-Blum, M., Sieber, F.: Tumor-Promoting Phorbol Esters Promote Melanogenesis and Prevent Expression of the Adrenergic Phenotype in Quail Neural Crest Cells 117

Siu, C. H., see Lam, T. Y., et al. 22

Slavkin, H. C., see Cummings, E. G., et al. 1

Sorof, S., see Schaefer, F. V., et al. 260

Sorof, S., see Tonelli, Q. J. 253

Stadler, J., see Franke, W. W., et al. 217

Sternfeld, J., David, C. N.: Cell Sorting During Pattern Formation in Dictyostelium 10

Tarin, D., see Price, J. E. 264

Tonelli, Q. J., Sorof, S.: Expression of a Phenotype of Normal Differentiation in Cultured Mammary Glands is Promoted by Epidermal Growth Factor and Blocked by Cyclic Adenine Nucleotide and Prostaglandins 253
Trendelenburg, M. F., see Williams, M. A., et al. 36

Tripiciano, A., see Liquori, A. M., et al. 174

Tsonis, P. A., Eguchi, G.: Carcinogens on Regeneration. Effects of $N$-Methyl- $N^{\prime}$-Nitro- $N$-Nitrosoguanidine and 4-Nitroquinoline-1-Oxide on Limb Regeneration in Adults Newts 52

Uçer, U., Engel, W.: The Effects of Neuraminidase and Gangliosides on Ovarian LH/hCG Receptors During Rat Development 162

Urban, E., see Müller, U. 274

Valle, G., see Colombo, R., et al. 45

Webb, C. G., Duksin, D.: Involvement of Glycoproteins in the Development of Early Mouse Embryos: Effect of Tunicamycin and $\alpha, \alpha^{\prime}$ Dipyridyl in vitro 81

Weber, K., see Osborn, M., et al. 196

Weirich, E., see Krepler, R., et al. 242

West, C. M., McMahon, D.: The Involvement of a Class of Cell Surface Glycoconjugates in Pseudoplasmodial Morphogenesis in Dictyostelium discoideum 61

Wieczorek-Engelken, G., see Epplen, J. T., et al. 124

Williams, M. A., Trendelenburg, M. F., Franke, W. W.: Patterns of Transcriptional Activity of Nucleolar Genes During Progesterone-Induced Maturation of Oocytes of Xenopus laevis 36

Winter, S., see Jackson, B. W., et al. 203

Zenzes, M. T., Engel, W.: The Capacity of Testicular Cells of the Postnatal Rat to Reorganize into Histotypic Structures 157 


\title{
Cell Sorting during Pattern Formation in Dictyostelium
}

\author{
JOHN STERNFELD and CHARLES N. DAVID \\ Department of Molecular Biology, Albert Einstein College of Medicine, Bronx, NY 10461, USA
}

Formation of the prestalk-prespore pattern in Dictyostelium was investigated in slugs and submerged clumps of cells. Prestalk and prespore cells were identified by staining with vital dyes, which are shown to be stable cell markers. Dissociated slug cells reaggregate and form slugs that contain a prestalk-prespore pattern indistinguishable from the original pattern. The pattern forms by sorting out of stained prestalk cells from unstained prespore cells. Sorting also occurs in clumps of dissociated slug cells submerged in liquid or agar. A pattern arises in $2 \mathrm{~h}$ in which a central core of stained cells is surrounded by a periphery of unstained cells. Sorting appears to be due to differential chemotaxis of stained and unstained cells to cAMP since exogenous cAMP $\left(>10^{-7} \mathrm{M}\right)$ reverses the normal direction of sorting-out such that stained cells sort to the periphery of the clumps.

Isolated portions of slugs regenerate a new prestalk-prespore pattern. Posterior isolates regenerate a pattern within $2 \mathrm{~h}$ due to sorting of a population of vitally stained 'anterior-like' cells present in posteriors. Anterior-like cells do not sort in intact slugs due to the influence of a diffusible inhibitor secreted by the anterior region. During posterior regeneration this signal is absent and anterior-like cells rapidly acquire the ability to sort. Anterior isolates regenerate a staining pattern more slowly than posterior isolates by a process that requires conversion of stained prestalk cells to unstained prespore cells.

The results suggest that pattern formation in Dictyostelium consists of two processes: establishment of appropriate proportions of two cell types and establishment of the pattern itself by a mechanism of sorting-out.

\section{Introduction}

During the life cycle of Dictyostelium a multicellular slug containing two cell types forms from an initially homogeneous population of cells. Prestalk cells occupy approximately the anterior $1 / 4$ and prespore cells the posterior $3 / 4$ of the slug. When the slug culminates to form a fruiting body, prestalk and prespore cells give rise to stalk cells and spores, respectively. The division line between prestalk and prespore tissue in the slug is sharp and the relative proportions are to a large extent independent of slug size [1]. When a slug is transected, the prestalk-prespore pattern can regenerate in the isolated pieces.

A number of models for formation of the prestalk-prespore pattern have been proposed (for a review see [2]). However, current information does not permit a choice between models and there is controversy about a central issue, the role of sorting-out. In an attempt to bring new experimental methods to bear on the problem, we have investigated the formation of the prestalk-prespore pattern in slugs and in clumps of cells in a submerged culture system [3]. To identify the pattern we have used vital dyes which stain prestalk cells but do not stain prespore cells. We have found that clumps containing randomly dispersed prestalk and prespore cells reform a prestalk-prespore pattern within $2 \mathrm{~h}$. There is no observable redistribution of vital dye during this period, and thus the results strongly suggest that the pattern is formed by sorting out of stained and unstained cells. Because the pattern in clumps can be perturbed in predictable ways by the application of exogenous cAMP, we suggest that sorting occurs by a mechanism of differential chemotaxis to cAMP.

We have also investigated the regeneration of staining patterns in clumps composed only of cells from anterior or posterior regions of slugs. Clumps of posterior cells form a pattern rapidly with stained cells at the center very much as do clumps consisting of cells from entire slugs. In this case, however, the pattern is due to sorting of stained 'anterior-like' cells that are present as a small population in the posterior portion of slugs. As with clumps of total slug cells, formation of this pattern can also be perturbed by application of low levels of exogenous cAMP. Clumps of anterior tissue also regenerate a staining pattern, but only after about $6 \mathrm{~h}$ by a process requiring conversion of stained anterior cells into unstained cells.

That 'anterior-like' cells sort out during posterior regeneration but are found in the posterior region in intact slugs suggests that their sorting-out is inhibited in slugs by the presence of anterior tissue. We have confirmed this by demonstrating: (1) that anterior tissue placed close to, but not in contact with, posterior tissue can inhibit pattern regeneration in posteriors; (2) that anterior-like cells are inhibited from sorting out during reformation of slugs from dissociated cells. It is possible that this inhibiton, which controls cell sorting in slugs, is involved in the normal process of proportion regulation in slugs. 


\section{Methods}

\section{Growth and Development}

Dictyostelium discoideum (strain NC-4, haploid) was grown at $21^{\circ} \mathrm{C}$ in liquid culture on live Klebsiella pneumonia (strain 29) in $17 \mathrm{mM}$ sodium-potassium phosphate buffer ( $\mathrm{pH}$ 6.6). Just as the cells cleared the bacteria, they were harvested in buffer and washed twice by centrifugation. When the cells were used to form slugs they were resuspended, after the last spin, in cold distilled water. We suspended $0.1-0.2 \mathrm{ml}$ of packed cells in about $0.4 \mathrm{ml}$ and spread them on fresh $2 \%$ unbuffered, nonnutrient agar in a $100-\mathrm{mm}$ petri dish. The petri dishes were kept in a moist chamber in a dark incubator at $21^{\circ} \mathrm{C}$. Slugs formed in approximately $12 \mathrm{~h}$, and they were used for experiments after $24-48 \mathrm{~h}$.

\section{Staining with Vital Dyes}

Neutral red (Sigma Chemical Co. St. Louis, MO, USA) or Nile blue A (Hartman-Leddon Co.) were used to stain the cells. After the first centrifugation, the cell pellet was resuspended in about $2 \mathrm{ml}$ of buffer. Four or five drops of a stock solution of either stain in distilled water $(20 \mathrm{mg} / \mathrm{ml})$ was added and the suspension was rapidly mixed. It was diluted immediately with more buffer to $12 \mathrm{ml}$ in the centrifuge tube. The cells were then washed twice in buffer before use. The staining procedure described permits the anterior-posterior staining pattern to be seen without affecting developmental timing or morphology. If more stain is accumulated by the cells it can slow development or kill cells.

When red and blue stained slugs were to be mixed, they were first transferred by mouth pipette to a small piece of polyester screen $(10 \mu \mathrm{m}$ pores; Tetko, Inc., Elmsford, NY, USA) on agar. This screen allows moisture to reach the cells while providing a solid support for mixing. Slugs were deposited on the screen and after a sufficient number were collected, they were carefully mixed with the tip of the pipette or an eyelash. The purple cell mass was then placed in droplets on fresh non nutrient agar in a moist chamber.

\section{Submerged Culture Methods}

Lack of sufficient oxygen is the principal factor limiting development in clumps of cells in submerged culture [3,4]. If the oxygen concentration is increased, development occurs in submerged cultures and the cells in clumps differentiate into stalk cells and spores. In the present experiments all submerged cultures were placed in a plastic box through which $100 \%$ oxygen was constantly flowing.

Calcium in the medium delays terminal differentiation and thereby preserves the anterior-posterior pattern for extended periods of time [5]. In the experiments reported here, Bonner's salt solution (BSS), which contains $2.7 \mathrm{mM} \mathrm{CaCl}_{2}$ [6], was used for the submerged culture. One $\mathrm{ml}$ of BSS was put into 2-ml wells in white plastic multi well plates (Linbro Division, Flow Lab. Inc. Hamden CT).

Development in Liquid. Clumps were made with the use of a small bore mouth pipette. Anteriors or posteriors of slugs were picked up directly with the pipette and deposited in the culture medium. If entire slugs were used, they were partially dissociated and scraped off an agar plate into BSS with a glass spreader. They were centrifuged once, most of the liquid was removed, and the pellet was spun again for $1 \mathrm{~min}$ at 2,500 rpm.
All of the remaining liquid was removed from the top of the tightly packed cell pellet and the cells were sucked up with the small bore pipette. The tip of the pipette was submerged in the solution in the wells and a cylinder of cells was extruded. Cylinders of cells of desired size were broken off by lifting the pipette out of the solution. The wells were then put into the oxygen box which was agitated on a shaker table at $150 \mathrm{rpm}$.

Development in Barriers. For some experiments cells were extruded from the pipette into holes in a sheet of lucite. The lucite was $1.0 \mathrm{~mm}$ thick. The holes, $0.33 \mathrm{~mm}$ in diameter, were about $1 / 3$ filled. Once filled, the lucite sheet was submerged in a finger bowl. Air bubbles trapped in the holes were carefully sucked out by pipette. The sheet of lucite was then placed as a barrier into a container which was thus divided into two water-tight chambers. After incubation, the lucite barrier was removed and one end of the clumps was marked with charcoal. The lucite sheet was then placed in a finger bowl and the clumps popped out by directing streams of water at the holes. The clumps were scored for the orientation of the pattern using the charcoal as a marker.

Development in Agar. One milliliter of 2\% agar in BSS was spread in a $60-\mathrm{mm}$ petri dish. When solidified a second layer of $0.8 \mathrm{ml}$ was spread over the first. Wells in the agar were made by removing plugs from the top layer with a thin-walled capillary pipette. Cells were placed in the wells with a small bore mouth pipette. As many as 100,000 cells can be put into a well. Then $0.8-1.0 \mathrm{ml}$ of $1 \%$ agar in BSS at $40-42^{\circ} \mathrm{C}$ was poured evenly over the entire plate to seal the cells in the wells. The petri dish was incubated in an oxygen box. Observations of the clumps in agar were usually made through the bottom of the petri dish.

For some experiments we put anterior and posterior slug cells on opposite sides of various filters. These filters were cut such that they were larger than the diameter of the wells. They were inserted vertically across the wells such that they were firmly embedded in the agar on both sides and across the bottom of the well. The two chambers made in this way were completely separated by the filter. Depending on the size of the slugs used as the source of tissue, one or two to several anteriors and posteriors were collected with a small bore pipette and transferred to either side of the filter. Then warm $1 \%$ agar was used to seal the tissue and the filter in the well.

\section{Terminology}

The main reason we find it necessary to define some terminology is that we have found two populations of cells in slug posteriors. One population stains with vital dyes like anterior cells. The vital dyes stain the anteriors of slugs darkly and posteriors lightly. We use the terms anterior cells and prestalk cells to refer to the darkly stained cells of the anterior region. We use the term posterior cells to refer to all of the cells of the posterior region. The term prespore cells is reserved for only those posterior cells which contain so little stain that they are essentially unstained. The term anterior-like cells refers to those cells in the posterior region which stain darkly like the anterior cells. We use the term stained cells to refer to anterior plus anterior-like cells. Unstained cells refer to the lightly stained prespore cells. 


\section{Results}

\section{Vital Staining of Slug Cells}

The results reported in this paper are based on observations of the anterior-posterior pattern in slugs as visualized with the vital dyes neutral red and nile blue. These dyes stain the anterior prestalk region darkly and the posterior prespore region lightly (see [7], Fig. 1E, G). When anterior and posterior portions of slugs are gently squashed and examined under high magnification with a light microscope the dye can be seen to be localized in large granules in the anterior cells. By comparison these granules are not present in most cells of the posterior region. It is important to note, however, that about $10 \%$ of posterior cells (Table 1) do contain granules. These cells are indistinguishable from anterior cells by vital staining and hence we refer to them as anterior-like cells.

Many of the experiments in this paper involve dissociation and mixing of vitally stained slug tissue. It is necessary, therefore, to show that the dyes, once localized in granules, are not exchanged between cells. To investigate the stability of the dyes, equal quantities of red and blue slugs were dissociated and mixed until the cell mass was a uniform purple color (Fig. 1A). When aliquots of the mixture were placed on agar, the cells reaggregated and formed purple slugs (Fig. 1B). When these slugs were dissociated and the cells examined at high magnification, they were found to contain either blue or red granules, not purple granules (Fig. 1C). Since the color of the granules in cells from mixed slugs was very similar to cells from either red or blue slugs, there appeared to be very little exchange of dye between cells during the $4 \mathrm{~h}$ of the experiment. Even if allowed to migrate for more than $30 \mathrm{~h}$, such slugs still contained only cells with red or blue granules.

The experiments above clearly indicate that vital dyes do not diffuse from cell to cell. However, if stained slugs were dissociated roughly or under conditions which killed cells (anterior cells are particularly fragile), then cell-mixing experiments like those described above yielded cells which contained purple granules. Presumably rough handling during mixing breaks some cells, releasing the dye and allowing it to be taken up by the remaining cells. This may be part of the explanation for earlier observations that vital dyes diffused from cell to cell [8].

\section{Pattern Formation and Sorting-out}

There are several reports of cell sorting during formation of the anterior-posterior pattern in slugs [9-14]. We have used slug cells stained with vital dyes to investigate this phenomenon in two experimental situations: reformation of slugs from dissociated cells on agar and formation of clumps in submerged culture.

When vitally stained slugs are dissociated and the cell mixture deposited on agar, slugs reform within $4 \mathrm{~h}$. The slugs exhibit a staining pattern with stained anteriors and pale posteriors that is essentially indistinguishable from that of the original slugs (Fig. 1E, G). Since vital dyes do not diffuse from cell to cell, the simplest interpretation of this result is that stained cells sort out from unstained cells in such a way that they occupy the anterior region of the new slug.

Although the above results appear to confirm earlier work, they do not rule out the possibility that the pattern is due to a change in the state of the dye from visible to bleached depending on the position of cells in slugs. To rule out this possibility and establish that the dyes are stable cell markers, anterior cells from neutral red stained slugs were mixed with posterior cells from nile blue stained slugs and allowed to reform slugs. Such slugs had well defined red anteriors and blue posteriors clearly demonstrating that the pattern is due to sorting out of anterior and posterior cells (Fig. 1D, F). Were the pattern due to the state of the dye (visible or bleached) at different positions in slugs and not to sorting out, then red and blue cells would be intermixed forming slugs with dark purple anteriors and pale purple posteriors. Furthermore, as discussed below, there is additional evidence that 'unstained' cells can not give rise to stained cells and therefore probably do not contain dye.

We have also investigated sorting out of anterior and posterior cells in clumps of cells submerged in liquid or embedded in agar [3, 4]. Slugs stained with vital dyes were dissociated and the cells used to form clumps. Initially such clumps appear uniformly stained due to the random distribution of stained and unstained cells. However, after $1.5-2 \mathrm{~h}$ a sharp pattern emerges in which a core of stained cells appears at the center of the clump surrounded by a shell of unstained cells (Figs. $1 \mathrm{H}$ and $2 \mathrm{~A}$ ). Within $1 \mathrm{~h}$ after formation, the stained region at the center moves to the edge of the clump (see Discussion). The pattern is extremely reproducible in clumps embedded in agar or simply submerged in liquid and is easily observed with vitally stained cells.

Although the conclusion that anterior and posterior cells can sort out to form patterns in slugs and in submerged clumps is in agreement with a number of previous observations of cell sorting in slugs, there remain conflicting ideas about the mechanism of sorting. Two mechanisms have been proposed: differential chemotaxis and differential adhesion. Matsukuma and Durston [15] have demonstrated differential chemotaxis of vitally stained and unstained cells toward cAMP and suggested that it might be involved in sorting-out. Tasaka and Takeuchi [16] have proposed that sorting of prestalk and prespore cells is due to differential adhesion of the two cell types. If sorting is due to differential chemotaxis toward cAMP, we expect that application of exogenous cAMP should perturb sorting behavior in a predictable manner. On the other hand, if sorting is due to differential adhesion of prestalk and prespore cells, then there is no a priori reason to expect cAMP to affect sorting behavior.

Table 1. The proportion of vitally stained cells in different regions of the slug

\begin{tabular}{llll}
\hline Whole slugs & Anteriors & Posteriors & $\begin{array}{l}\text { Secondary } \\
\text { posteriors }\end{array}$ \\
\hline $17.2 \%$ & $99.4 \%$ & $9.7 \%$ & $1.7 \%$ \\
$(6,434)$ & $(2,294)$ & $(12,169)$ & $(5,656)$ \\
\hline
\end{tabular}

Cells were stained with neutral red and allowed to develop on agar for 24-30 h. A mouth pipette was used to transfer slugs or portions of slugs to a small drop of buffer on a microscope slide. The cells were dissociated by pipetting. When posterior slug tissue was allowed to regenerate in submerged culture a new anterior-posterior pattern formed after $3-5 \mathrm{~h}$. The new, 'secondary posteriors' were collected and dissociated on a microscope slide. Stained and unstained cells (single cells and cells in small clumps) were counted in each sample. Each sample consisted of several slugs or slug portions, and between 500 and 600 cells were counted from each sample. The total number of cells counted is shown in the parentheses. Because anterior cells tend to remain in clumps, the number of stained cells in whole slugs is probably an undercount 

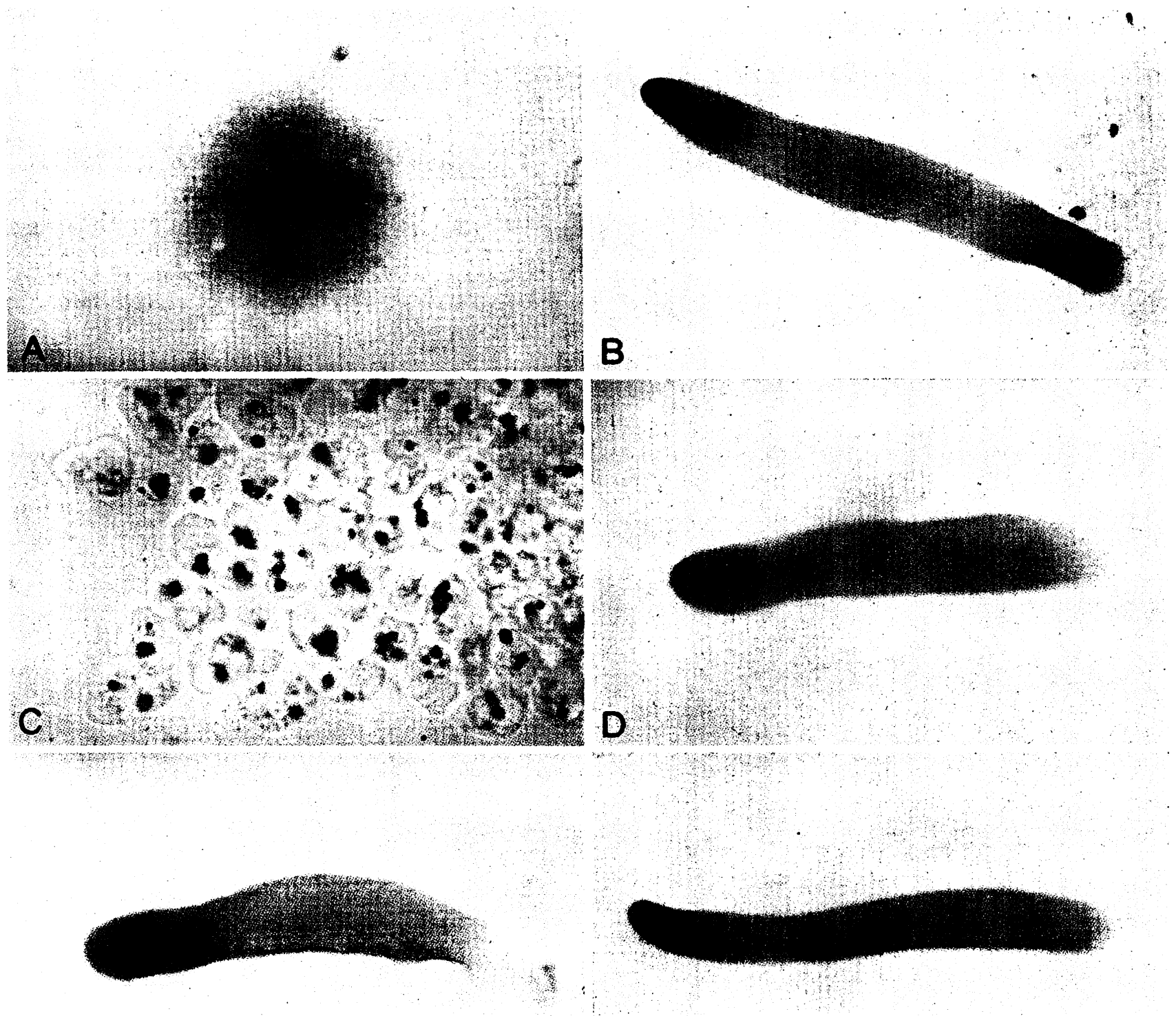

E
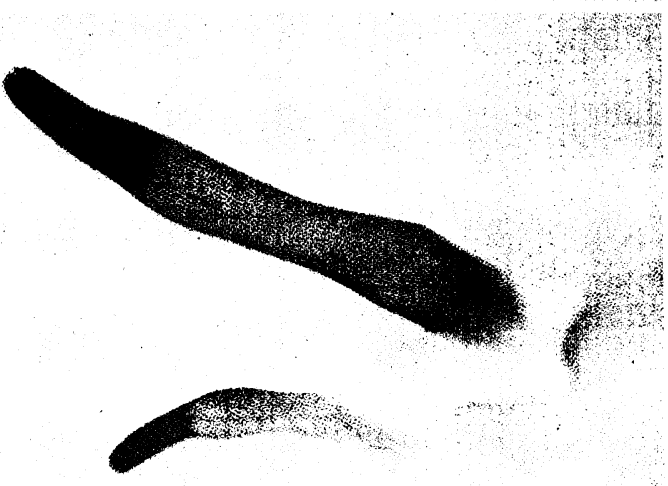

G
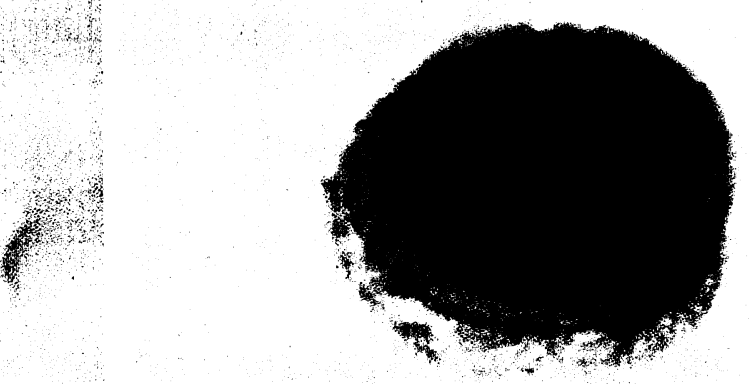

Fig. 1. (Legend see p. 14) 


\section{Effect of cAMP on Sorting Out}

To test the effects of cAMP on cell sorting, we have used the submerged culture system because it permits us to apply the cAMP in a controlled manner to a mass of cells in which sorting is occurring. To apply cAMP locally to one end, clumps of vitally stained slug cells were placed in holes in a lucite barrier mounted between two chambers, one containing BSS and one containing BSS and $10^{-6} \mathrm{M}$ cAMP. When oxygen was bubbled into both chambers, patterns formed by the sorting-out of stained and unstained cells. When cAMP was present on one side of the barrier, all the clumps formed patterns with stained cells at the end of the clump exposed to cAMP. However, when no CAMP was present, the patterns were oriented with equal frequency toward either chamber. This result clearly shows that cAMP is a chemotactic attractant for stained cells and, since stained cells sort out from unstained cells, stained and unstained cells must be differentially chemotactic toward cAMP in agreement with the results of Matsukuma and Durston [15].
This observation suggests that formation of a core of stained cells in submerged clumps is due to an endogenous gradient of cAMP with the highest concentration at the center of the clump. Such a gradient would develop if cAMP were secreted by cells in the clumps and lost by diffusion at the periphery. If this interpretation is correct, it should be possible to reverse the sorting pattern by exposing clumps to cAMP. To test this we immersed clumps of vitally stained slug cells in several concentrations of cAMP from $1 \times 10^{-8}$ to $8 \times 10^{-5} \mathrm{M}$. In controls without cAMP, the clumps rounded up to form spheres and the stained cells sorted to the center (Fig. 2A, B). Similar results were obtained in clumps exposed to cAMP concentrations $<4 \times 10^{-8} \mathrm{M}$. Between $1 \times 10^{-7}$ and $5 \times 10^{-6} \mathrm{M}$ cAMP the clumps rounded up, but had a uniform dark appearance (Fig. 2C; Table 2). When a section was cut out of the center of these clumps it could be seen that the darkly stained cells had moved to the periphery rather than the center (Fig. 2D). If clumps with stained cells at the periphery attach to the substrate they flatten out in a disc. The cells continue to move outward on the bottom of the well forming

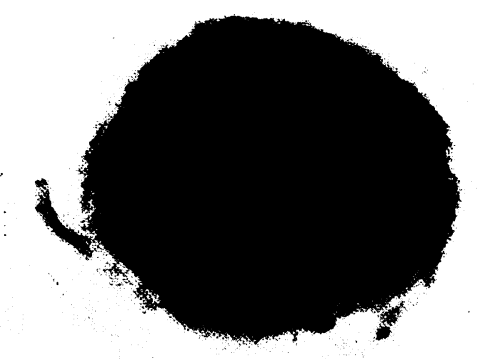

A

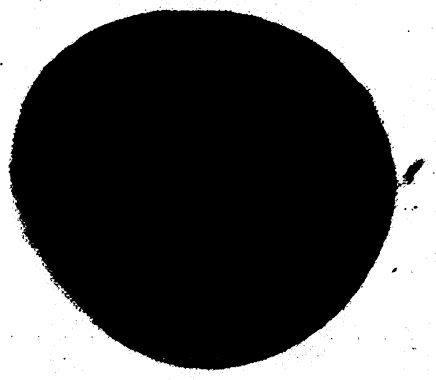

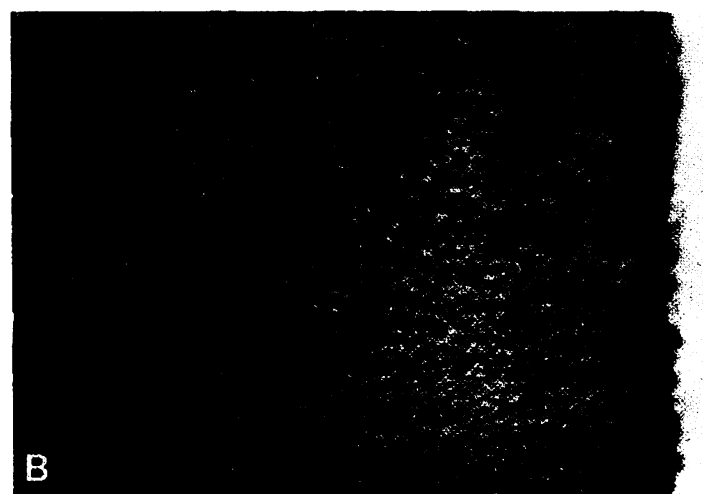

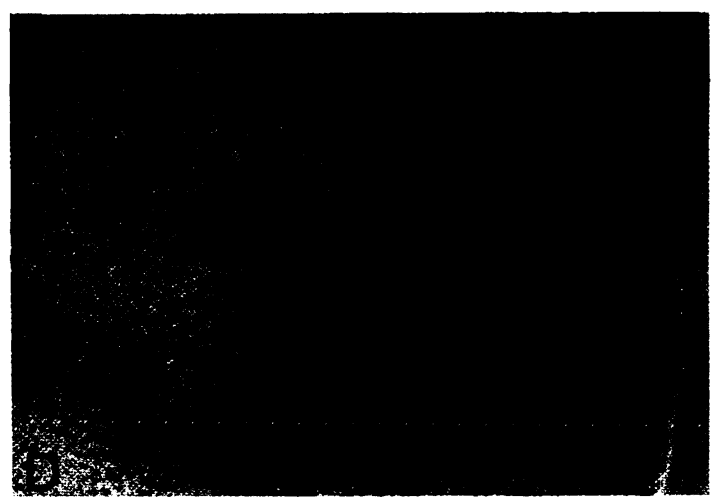

Fig. 2. Cell sorting patterns in submerged clumps. Clumps were prepared from dissociated neutral red stained slugs and incubated in suspension in BSS $(\mathbf{A}, \mathbf{B})$ or in $1 \times 10^{-6} \mathrm{M}$ cAMP in BSS (C, D). A Clump in BSS showing the typical central core of stained cells. B Section through the center of the clump shown in A. C Clump in $1 \times 10^{-6} \mathrm{M}$ cyclic AMP showing the typical shell of stained cells. D Section through the center of the clump shown in $\mathbf{C}$. The clumps in $\mathbf{A}$ and $\mathbf{C}$ are about $0.4 \mathrm{~mm}$ in diameter; $\mathbf{B}$ and $\mathbf{D}$ show sections from the edge to the center of the clumps

Fig. 1. Cell sorting patterns in slugs and submerged clumps prepared from vitally stained slug tissue. Stationary phase cells were stained with neutral red or nile blue and allowed to form slugs on agar. After $24-48 \mathrm{~h}$ slugs containing a clear anterior-posterior staining pattern were harvested, dissociated, and mixed on an agar surface. A Freshly dissociated mixture of neutral red and nile blue stained slugs. Dissociation and mixing are fairly complete although small clumps (10-50 cells) of the original red or blue tissue can be seen. B Purple slug which formed by reaggregation of dissociated cells shown in $\mathbf{A}$. C Portion of the anterior of the slug in $\mathbf{B}$ gently squashed under a coverslip. Note that the cells contain large staining granules which are either red or blue. D, F Slugs which reformed from a dissociated mixture of red anterior and blue posterior tissue, and blue anterior and posterior tissue, respectively. $\mathbf{E}$ slug formed from cells stained $24 \mathrm{~h}$ previously showing the typical neutral red staining pattern. G Slugs which reformed after dissociation of the slug in $\mathbf{E}$. $\mathbf{H}$ Clump prepared from dissociated nile blue stained slug cells and embedded in agar. The clump is shown after $2 \mathrm{~h}$ of incubation under oxygen when the typical central core of stained cells has formed. Magnifications: $\mathbf{A}$ Cell mass is about $5 \mathrm{~mm}$ in diameter; B, D-G the slugs are about $0.6-1.0 \mathrm{~mm}$ in length; $\mathbf{C}$ the cells are about $15 \mu \mathrm{m}$ in diameter; H the clump is about $0.3 \mathrm{~mm}$ long 
Table 2. Effect of cyclic AMP on sorting pattern in submerged clumps

\begin{tabular}{|c|c|c|c|c|c|c|c|c|c|c|c|}
\hline \multirow{2}{*}{$\begin{array}{l}\text { Source } \\
\text { of } \\
\text { cells }\end{array}$} & \multirow{2}{*}{$\begin{array}{l}\text { Type } \\
\text { of } \\
\text { sort- } \\
\text { ing }\end{array}$} & \multirow[t]{2}{*}{ BSS } & \multicolumn{9}{|c|}{ Cyclic AMP concentration $\left(\times 10^{-7} \mathrm{M}\right)$} \\
\hline & & & 0.1 & 0.2 & 0.4 & 0.6 & 0.9 & 1.3 & 2.0 & 3.0 & 4.5 \\
\hline $\begin{array}{l}\text { Whole } \\
\text { slugs }\end{array}$ & $\begin{array}{l}C \\
P\end{array}$ & 36 & 15 & 15 & $\begin{array}{r}11 \\
1\end{array}$ & $\begin{array}{l}8 \\
4\end{array}$ & $\begin{array}{r}2 \\
10\end{array}$ & 12 & 12 & 12 & 12 \\
\hline $\begin{array}{l}\text { Pos- } \\
\text { teriors }\end{array}$ & $\begin{array}{l}C \\
P\end{array}$ & 15 & 8 & 7 & 9 & $\begin{array}{l}5 \\
2\end{array}$ & $\begin{array}{l}2 \\
4\end{array}$ & $\begin{array}{l}1 \\
5\end{array}$ & 6 & 7 & 6 \\
\hline
\end{tabular}

Slugs with a clear neutral red staining pattern were harvested, dissociated, and used to make clumps. Two or three clumps were placed in Linbro wells containing $1 \mathrm{ml}$ of BSS or cAMP and shaken gently under $100 \%$ oxygen atmosphere. After $2 \mathrm{~h}$ incubation, clumps were scored for pattern. The results are given as the number of clumps in which stained cells sorted to the center $(C)$ or periphery $(P)$, respectively

first a toroid and finally several crescents as the circumference becomes larger. Above $5 \times 10^{-6} \mathrm{M}$ cAMP the clumps formed multiple tips, similar to the observations of Nestle and Sussman [17].

The effect of cAMP in perturbing the sorting behavior in submerged clumps appears to be specific since 5'AMP, adenosine, and cGMP do not affect the sorting pattern at any concentration from $4 \times 10^{-8} \mathrm{M}$ to $4 \times 10^{-5} \mathrm{M}$. As in the lucite barrier experiments above, the submerged clump results clearly suggest the slug cells are differentially chemotactic toward cAMP; stained cells move toward cAMP more effectively than unstained cells. The sharpness of the transition from inside sorting to outside sorting is interesting. One might have expected an intermediate result - no sorting - at cAMP concentrations roughly equivalent to endogenous concentrations. That this result is not observed may, however, be a reflection of the fact that stained cells themselves secrete cAMP (see Discussion); any small concentration of such cells is self-reinforcing and might dominate over exogenous signals.

\section{Pattern Regeneration in Anteriors and Posteriors}

From the work of Raper [18] and Bonner [7] it has been known that, if slugs are transected at the anterior-posterior boundary, each portion will regenerate a new pattern. We have examined the reestablishment of staining patterns in clumps of posterior cells and clumps of anterior cells stained with vital dyes. We find that clumps made from posterior regions regenerate a pattern in about $1.5-2 \mathrm{~h}$. The stained cells appear first at the center of the clump and then move to one side in the same manner as pattern formation in a clump consisting of the tissue from entire slugs. Regeneration in anteriors, on the other hand, must proceed at least $6 \mathrm{~h}$ before there is any sign of a pattern of stained cells.

The similarity of pattern regeneration in isolated posterior tissue to that of tissue from entire slugs suggests that this pattern is also a result of cell sorting. In this case, however, it is the population of stained anterior-like cells that appear to sort out from the unstained cells. To establish that the pattern in this regeneration situation is due to movement of cells and not simply to exchange of dye between cells, we observed pattern regeneration in clumps containing a mixture of posteriors from neutral red and posteriors from nile blue stained slugs. Such clumps formed patterns with a purple core. However, when the cells in the purple core were examined at high magnification they were observed to contain either red or blue granules and not purple granules. Thus even under regeneration conditions, vital dyes are not exchanged between cells. Hence the staining pattern which forms during regeneration is due to sorting of the cells themselves.

We have confirmed that pattern regeneration in isolated posterior tissue is due to sorting of anterior-like cells by scoring the loss of these stained cells from the 'posterior' region of clumps which have regenerated a new pattern. Clumps were prepared from posteriors of stained slugs and incubated in BSS under $100 \%$ oxygen. After 3-5 h when the newly formed core of stained cells had moved to one side, the remaining unstained 'posterior' tissue was removed, dissociated, and scored for stained cells (Table 1, Secondary Posteriors). The results indicate that the number of stained cells in the newly regenerated 'posterior' was significantly reduced compared to the original posterior tissue and, thus, it is clear that anterior-like cells make a major contribution to the formation of the new anterior region during regeneration of isolated posteriors.

The sorting-out of stained anterior-like cells during posterior regeneration can also be demonstrated by observing the pattern formed during a second round of regeneration. Posteriors from stained slugs were collected and placed in submerged culture. After the regeneration of a staining pattern in the clumps, the stained core was removed and the remaining tissue allowed to regenerate a second time. The staining pattern formed in such clumps was very faint compared to the pattern formed after the first round of regeneration. This is expected if anterior-like cells are the principal source of cells of the stained region during regeneration of isolated posterior tissue. The results also suggest that unstained cells do not contain dye since these cells are not able to express the dye when they become anterior cells in the course of a second round of regeneration.

To determine if the sorting of anterior-like cells occurs by chemotaxis toward cAMP, we tested the ability of exogenous cAMP to disturb the pattern of regeneration in submerged clumps of posterior cells. The results (Table 2) were identical to those using tissue from the entire slug: stained cells sort to the center of clumps when exogenous cAMP is less than $4 \times 10^{-8} \mathrm{M}$ but sort to the outside of clumps incubated in higher concentrations of cAMP. Thus, under regeneration conditions, anterior-like cells are similar to anterior cells in their chemotactic sensitivity to cAMP.

Regeneration of an anterior-posterior staining pattern in clumps of anterior cells requires notably longer than pattern regeneration of isolated posterior tissue. Since anterior regions contain only stained cells (Table 1 ), formation of a pattern must be preceded by the conversion of some stained cells into unstained cells. This process appears to require $>6 \mathrm{~h}$ since prior to that time there is no evidence of a staining pattern in isolated anteriors.

\section{Anterior Cells Prevent Sorting in Posteriors}

The observations above indicate that anterior-like cells are chemotactic to cAMP and capable of sorting-out in isolated posteriors. Nevertheless such cells are maintained in the posterior regions of intact slugs and obviously do not sort out. One possible resolution of this apparent paradox is to assume that anterior-like cells are prevented from sorting in intact 
slugs due to an inhibitory influence from the anterior region. When the inhibition is eliminated by removal of anterior cells, the anterior-like cells acquire the ability to sort out. We have tested this hypothesis by placing anterior and posterior cells on opposite sides of permeable filters and scoring the ability of anterior cells to inhibit formation of the inside-outside sorting pattern characteristic of regenerating posterior tissue.

For these experiments, anteriors and posteriors from vitally stained slugs were transferred separately to opposite sides of various filters or barriers embedded vertically in an agar well (see Methods). The entire well was then sealed with warm soft agar and exposed to an oxygen atmosphere. Regeneration of the characteristic inside-outside sorting pattern was scored in the posterior tissue after $2-3 \mathrm{~h}$. The results are shown in Table 3 as the percent of posteriors in which no pattern was observed (percent inhibition). When posterior cells were placed on one side of a well and no anterior cells on the other, each posterior clump regenerated the characteristic pattern with stained cells at the center $(0 \%$ inhibition). Similarly when a piece of glass coverslip or aluminum foil was used to divide the well, essentially all posteriors formed the typical pattern and there was no inhibiton by the anterior cells across the barriers. Conversely, when no barrier was placed in the well, the anterior and posterior cells fused to form one cell mass. Under these conditions about $80 \%$ of posteriors showed no evidence of stained cells sorting to the center; the remaining $20 \%$ formed patches of stained cells in the posterior region. With further incubation these patches usually fused with the large anterior region. Thus in about $80 \%$ of cases we can reconstruct the situation in slugs in which anterior-like cells are inhibited from sorting out.
Significant inhibition of sorting in posteriors also occurred when Nucleopore filters ( $12 \mu \mathrm{m}$ or $0.4 \mu \mathrm{m}$ pore size) were used to separate anterior from posterior tissue (Table 3). Although the extent of inhibition was somewhat less with filters $(49-63 \%)$ than without filters $(79 \%)$, the difference appears small compared to the $90 \%$ decrease in open area between the two sides caused by the filters (only about $10 \%$ of filter surface consists of pore). It is also interesting to note that decreasing pore size from $12 \mu \mathrm{m}$ to $0.4 \mu \mathrm{m}$ did not greatly affect inhibition, although it probably reduced the degree of cell contact within pores [19]. Both of the above observations suggest that cell contact is not required for inhibition, and thus they raise the possibility that inhibition is mediated by a diffusible extracellular signal.

To distinguish more clearly between the alternatives of cell contact and a diffusible signal, we modified the filter technique by removing the filters and leaving only a liquid-filled gap between the anterior and posterior tissue. This was done by using a millipore filter $(150 \mu \mathrm{m}$ thick) to divide an agar well. Anterior and posterior cells were placed on either side of the filter and sealed in with agar. Immediately thereafter the filter was removed from the well. In $2 / 3$ of the wells the clumps fell together and fused. In the remaining cases, gaps of $20-100 \mu \mathrm{m}$ were left between the clumps. (In none of the cases in which there was an observable gap were any cells seen in the gap under the high power of a dissecting microscope.) After 2-3 h posterior regions were examined for the appearance of patterns. In $53 \%$ of the cases the posterior regions were inhibited from forming patterns (Table 3). This experiment confirms that the anterior influence on sorting in posteriors does not require cell contact, but is mediated by a diffusible signal.
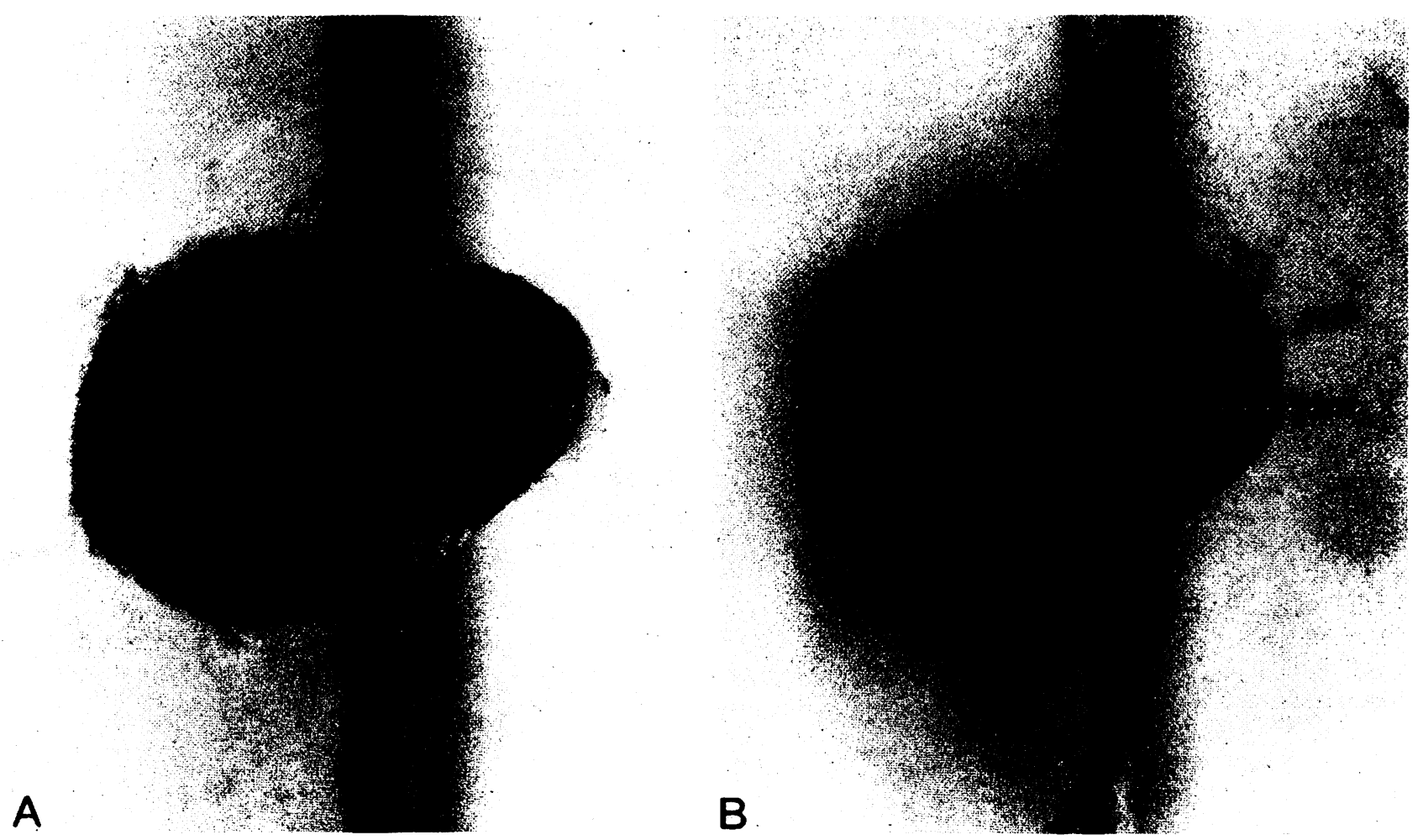

Fig. 3. Assay for inhibition of anterior-like cell sorting by anterior tissue. Anterior and posterior tissue from neutral red stained slugs were placed on opposite side of Nucleopore filters in agar wells. Anterior tissue is on the left, posterior tissue on the right. After about $2 \mathrm{~h}$ of incubation under oxygen, the staining pattern in the posterior tissue was scored. A An example in which sorting occurred in the posterior clump giving rise to the typical central core of stained anterior-like cells. B An example in which sorting was inhibited in the posterior clump 
Table 3. Anterior inhibition of sorting in posteriors

\begin{tabular}{|c|c|c|c|c|}
\hline \multirow{3}{*}{$\begin{array}{l}\text { Barrier } \\
\text { None }\end{array}$} & \multicolumn{2}{|l|}{ Tissue } & \multirow{2}{*}{\multicolumn{2}{|c|}{$\begin{array}{l}\% \text { of } \\
\text { posteriors } \\
\text { inhibited }\end{array}$}} \\
\hline & \multirow{2}{*}{$\begin{array}{l}\text { leftside } \\
-\end{array}$} & \multirow{2}{*}{$\begin{array}{l}\text { rightside } \\
P\end{array}$} & & \\
\hline & & & $0 \%$ & (171) \\
\hline None & A & $\mathbf{P}$ & $79 \%$ & (71) \\
\hline Glass & A & $\mathbf{P}$ & $0 \%$ & (13) \\
\hline Aluminium foil & A & $\mathbf{P}$ & $0 \%$ & (45) \\
\hline $\begin{array}{l}12 \mu \mathrm{m} \\
\text { Nucleopore filter }\end{array}$ & A & $\mathbf{P}$ & $63 \%$ & (52) \\
\hline $\begin{array}{l}0.4 \mu \mathrm{m} \\
\text { Nucleopore filter }\end{array}$ & A & $\mathbf{P}$ & $49 \%$ & (45) \\
\hline $\begin{array}{l}\text { Liquid-filled } \\
\text { gap }(20 \mu \mathrm{m}-100 \mu \mathrm{m})\end{array}$ & A & $\mathbf{P}$ & $53 \%$ & (36) \\
\hline $\begin{array}{l}0.4 \mu \mathrm{m} \\
\text { Nucleopore filter }\end{array}$ & $\mathbf{A}$ & $A+P$ & $12 \%^{\mathrm{a}}$ & (45) \\
\hline
\end{tabular}

${ }^{\text {a }}$ Clumps contain cells from entire slug

$\mathrm{A}=$ anterior cells

$\mathrm{P}=$ posterior cells

Anteriors and posteriors were collected from slugs with a clear neutral red staining pattern and sealed in wells in agar on opposite side of various barriers (see Fig. 3). A typical sorting pattern with stained cells at the center appeared in control posterior clumps (first row) after $1.5-2 \mathrm{~h}$ incubation in an oxygen atmosphere. One half hour after the appearance of patterns in control clumps, experimental clumps were scored. Clumps without patterns at that time were scored as inhibited (Fig. 3B); clumps with any trace of a developing pattern were scored as uninhibited (Fig. 3A). When no barrier was used (second row), the two tissue masses fused. When the barrier was removed after sealing the preparation with warm agar, the two tissue masses fused in about two-thirds of the cases, while in one-third of the cases (seventh row) they remained as two clumps separated by a liquid-filled gap. In one set of experiments (last row), tissue from the entire slug was used in place of posterior tissue on the right side of the barrier. The results shown are the sum of a number of independent experiments. The total number of clumps scored is given in parentheses

Since cAMP is known to be produced and secreted by anterior tissue [20-24] we considered the possibility that cAMP at some concentration might inhibit sorting of anterior-like cells in slugs. If cAMP were the inhibitory influence preventing anterior-like cells from sorting in slugs, then incubation of isolated posteriors in cAMP might be expected to inhibit sorting as well. This effect was clearly not observed (Table 2). While we can not replace the inhibitory effect of anteriors with constant concentrations of cAMP up to $4 \times 10^{-5} \mathrm{M}$, it remains possible that pulses of cAMP are inhibitory.

\section{How Different are Anterior and Anterior-Like Cells?}

Our results indicate that anterior cells can inhibit the sorting behavior of anterior-like cells in posterior tissue thereby explaining the presence of anterior-like cells in slug posteriors. To determine whether anterior cells were inhibited under these same conditions we placed anteriors on one side of $0.4 \mu \mathrm{m}$ filters and tissue from entire slugs on the other. In this case only $12 \%$ of the clumps of whole slug tissue were inhibited (Table 3) indicating that anterior cells can sort in the presence of anterior tissue.
The difference in sorting behavior of anterior and anterior-like cells provides a simple explanation for the distribution of these cells in slugs: anterior cells sort to form an anterior region; anterior-like cells are inhibited from sorting and remain distributed in posteriors. To test this explanation directly we labeled anterior and anterior-like cells differentially with vital dyes and observed their sorting behavior during reformation of slugs from dissociated slug tissue. Anterior regions from nile blue stained slugs were dissociated and mixed on the surface of agar in approximately normal proportions with dissociated posterior regions from neutral red stained slugs. In this experiment, described earlier to illustrate a separate point, slugs reorganized from the purple cell mass and the patterns were examined after $4-5 \mathrm{~h}$ when the slugs lay horizontally on the agar. In all cases the fronts of the slugs were blue and the backs red indicating that anterior and anterior-like cells differ in their sorting behavior (Fig. 1F; Table 4). As a control we mixed tissue collected from entire slugs stained either with neutral red or nile blue. In all cases the slugs which reformed from such mixtures were purple (Fig. 1B; Table 4).

The observation that anterior and anterior-like cells sort respectively to the front and the back of slugs indicates that large portions of these two populations differ in their sorting behavior. The purple zone in the middle of some slugs may indicate that the anterior and anterior-like populations overlap somewhat in their sorting properties or may be because dissociation and mixing on agar effectively removes anterior inhibiton long enough for some anterior-like cells to acquire the ability to sort. The present results do not permit a distinction between these possibilities.

These results are further evidence that anterior and anterior-like cells are not equivalent. Nevertheless, anterior-like cells have the ability to convert into anterior cells during regeneration of isolated posteriors. To study the timing of this process we used the slug mixing procedure described above and examined the relative abilities of anterior and anterior-like cells to sort out. We isolated neutral red stained posterior regions and permitted them to reorganize on agar for various times before mixing with freshly isolated blue anteriors. When posteriors were incubated for about $1.5 \mathrm{~h}$ before mixing with fresh anterior tissue, the anterior-like cells acquired an ability to sort out equal to that of anterior cells, and slugs with purple fronts were formed (Table 4). With shorter periods of regeneration, anterior-like cells sorted out from anterior cells.

\section{Discussion}

The results described in this paper have been made possible by observing Dictyostelium development in clumps of cells submerged in liquid or embedded in agar and by the demonstration that vital dyes are stable markers for anterior cells and a subset of posterior cells. There are four principal findings:

1. Clumps formed from dissociated slug tissue rapidly form patterns in which stained and unstained cells sort out by a mechanism of differential chemotaxis to cAMP.

2. Posteriors contain a population of cells which stain with vital dyes like anterior cells but which are not chemotactically sensitive to cAMP while part of an intact slug.

3 . In the absence of a diffusible inhibitor secreted by anterior cells, anterior-like cells develop chemotactic sensitivity to cAMP and sorting behavior similar to anterior cells. 
Table 4. Sorting behavior of anterior and anterior-like cells

\begin{tabular}{|c|c|c|c|c|c|}
\hline \multirow{2}{*}{\multicolumn{2}{|c|}{$\begin{array}{l}\text { Source and color } \\
\text { of tissue }\end{array}$}} & \multicolumn{4}{|c|}{$\begin{array}{l}\text { Distribution of red and blue cells in newly formed slugs } \\
\text { (front/back) }\end{array}$} \\
\hline & & \multirow{2}{*}{$\begin{array}{l}\text { Purple/purple } \\
50\end{array}$} & \multirow[t]{2}{*}{ Blue/red } & \multirow[t]{2}{*}{ Purple/red } & \multirow{2}{*}{$\begin{array}{l}\text { Blue/purple/red } \\
1\end{array}$} \\
\hline $\begin{array}{l}\text { Whole } \\
\text { blue } \\
\text { slugs }\end{array}$ & $\begin{array}{l}\text { Whole } \\
\text { red } \\
\text { slugs }\end{array}$ & & & & \\
\hline $\begin{array}{l}\text { Blue } \\
\text { anteriors }\end{array}$ & $\begin{array}{l}\text { Red } \\
\text { posteriors }\end{array}$ & & 50 & 2 & \\
\hline $\begin{array}{l}\text { Blue } \\
\text { anteriors }\end{array}$ & $\begin{array}{l}\text { Whole red } \\
\text { slugs }\end{array}$ & & & 65 & 5 \\
\hline $\begin{array}{l}\text { Blue } \\
\text { anteriors }\end{array}$ & $\begin{array}{l}2 \mathrm{~h} \text { isolate } \\
\text { red posteriors }\end{array}$ & & & 59 & 1 \\
\hline
\end{tabular}

Cells were stained with neutral red or nile blue and allowed to develop on agar. After 24-48 h, when slugs had clear anterior-posterior staining patterns, entire slugs or portions of slugs were mixed and dissociated as indicated in the left column. The approximate proportions of each tissue type are given in parenthesis. After $4-5 \mathrm{~h}$, when slugs had reformed from the dissociated cells, they were examined for the distribution of red and blue cells. The results were scored in four categories reflecting the distribution of red and blue cells from front to back along the slug axis

Purple/purple: Slugs are completely purple; anterior regions are darker than posterior regions (see Fig. 1B) Blue/red and purple/red: Front of the slug blue (see Fig. 1F) or purple; back of the slug red. Fronts were generally all blue or all purple although a few slugs with purple fronts had very small blue tips due to incomplete dissociation of the blue anterior tissue

Blue/purple/red: All three colored zones are large; some of these slugs appear to result from incomplete dissociation or inhomogenous distribution of red and blue cells in the reaggregating mass

4. In addition to rapid sorting of stained and unstained cells, there is a slower process of interconversion of stained and unstained cells when the relative proportions of these cells are experimentally altered from those normally found in slugs.

In the following we discuss these findings in relation to several aspects of slug development and pattern formation.

\section{Vital Dyes are Stable Cell Markers}

Vital dyes stain lysosomes and phagocytic vacuoles in a variety of cells [25]. The mechanism of staining appears to depend on the fact that such dyes are weak bases, which can permeate cell membranes in the uncharged form, but become trapped in the acidic environment of lysosomes in the protonated form [25]. Once trapped inside such vacuoles, the dyes are stable; indeed, the vacuoles retain their stain when isolated from cell homogenates by isopynic centrifugation [25].

In differentiating Dictyostelium cells, vital dyes accumulate in prestalk cells as large granules, which are easily seen in the light microscope, while in prespore cells the stained granules are small and difficult to detect. It seems likely that the stain is contained in autophagic vacuoles since, as mentioned above, vital dyes have been shown to stain these organelles in other systems. This interpretation is supported by the observation that autophagic vacuoles containing acid phosphatase [26] exhibit a size distribution in slug cells similar to that of the vitally stained granules. In addition, we have shown that vital dyes are stably bound in Dictyostelium cells (Fig. 1) as they are in lysosomal vacuoles in fibroblasts [25]. The apparent specificity of vital dyes for prestalk cells is due to the difference in size of autophagic vacuoles in prestalk and prespore cells: prestalk cells accumulate more dye in their larger vacuoles and appear stained in the light microscope, whereas prespore cells accumulate less dye in their smaller vacuoles and appear unstained.

\section{Anterior-like Cells}

Vital dyes stain all of the cells in the anteriors of slugs and about $10 \%$ of the cells in the posteriors (Table 1). Stained cells in the posterior appear to be very similar to anterior cells; however, because their position in slugs is different from anterior cells, we have termed them anterior-like cells. It seems likely that anterior-like cells identified by vital staining are the same as subpopulations of posterior cells described previously by electron microscopy as lacking prespore vesicles [27-32] or by antibody staining as lacking prespore antigen [33]. It is thus interesting to note that estimates of the size of all three populations are about the same (Table $1 ;[31,33]$ ).

Despite the similarity in vital staining between anterior and anterior-like cells, the results presented here indicate that these two populations are not identical, but differ in their ability to sort out. In direct competition experiments during slug reformation anterior cells sorted to the front of slugs whereas anterior-like cells sorted toward the back (Fig. 1D, F). Furthermore, the results in Table 3 indicate that anterior tissue secretes a diffusible inhibitor which can inhibit sorting behavior of anterior-like cells but not anterior cells. Nevertheless, anterior-like cells must be rather similar to anterior cells since they acquire, in about $1.5 \mathrm{~h}$, the ability to sort when removed from the influence of anteriors. This conversion from anterior-like to anterior is rapid compared to the intercon- 
version of prestalk and prespore cells that requires $>6 \mathrm{~h}$ ([33], see Results).

It is interesting to consider the possible fates of the anterior-like cells in various circumstances. During fruiting it is possible that the anterior-like cells are released from inhibition as the anterior cells differentiate into stalk cells. This would permit them to sort out to the anterior, and possibly differentiate into stalk cells themselves. During migration some of the anterior-like cells, in view of their tendency for stalk differentiation, may contribute to the prebasal disc region. The cells in this region form the stalk-like basal disc cells of the fruiting body. This possibility is supported by observations of Bonner and of Sampson. Bonner's [34] observations imply that the prebasal disc cells must be continuously replaced as these cells are lost during migration. Further Sampson's [35] experiments imply that the anterior-like cells are depleted during prolonged migration. $\mathrm{He}$ showed that the older the slug the smaller the percentage of stalk cells in the fruiting body formed from isolated posterior tissue. Before depletion by such a prolonged migration, the anterior-like cells may play a role of evolutionary significance. If a slug is disrupted, the anterior-like cells permit the posterior region to reform a new anterior quickly. This is of prime importance because the remaining posterior cells become the spores of the next generation and without an anterior, the posterior will not continue to migrate and a stalked fruiting body will not be formed. It is important for the slug to be reformed quickly, as it is very susceptible to environmental factors such as dessication.

\section{Pattern Formation by Sorting Out}

The present results demonstrate in a particularly clear way that mixtures of anterior and posterior cells sort out to establish patterns and that this process is rapid. Nevertheless, the suggestion that sorting of anterior and posterior cells is involved in pattern formation in slugs is not new. Both Bonner [9] and Takeuchi [10] provided evidence for sorting based on observations that mixtures of two cell types gave rise to slugs in which the two cell types were nonrandomly distributed along the axis of the slug. Subsequently several laboratories [11-14] identified properties of preaggregation cells which were correlated with sorting behavior [14]. Furthermore, Takeuchi [11], using slug-stage cells, showed that posterior cells, when dissociated and allowed to reaggregate with anterior cells, tended to sort to the posterior region of the new slug. While all these results provided evidence for sorting, they also indicated that sorting of, for example, anterior and posterior cells [11] did not produce as sharp a boundary as the prestalk-prespore boundary in slugs. By comparison, our results with vitally stained tissue indicate that sorting yields sharp boundaries between stained and unstained regions (Fig. 1D-H). Tasaka and Takeuchi [16] have also observed sharp boundaries between prespore and prestalk cells in submerged aggregates prepared from dissociated slug tissue and stained with spore antiserum.

There appear to be several possible explanations for the failure to observe precise cell sorting. For example, the observation of some labeled posterior cells sorting to the anterior of slugs [11] could be due to anterior-like cells which acquired the ability to sort during manipulations involved in the experiment. Alternatively, we have found that, if anterior and posterior cells are not mixed in the proportions which occur in slugs, then the cell type in excess tends to smear into the opposite region. With correct proportions it is possible to obtain fairly complete sorting with sharp boundaries between the anterior and posterior regions (Fig. 1D-H).

Our results demonstrate that sorting of anterior and posterior cells occurs by differential chemotaxis to cAMP. These observations confirm, and in fact were stimulated by, earlier observations of Matsukuma and Durston [15] showing that vitally stained cells from slugs would respond chemotactically to cAMP. An interesting corollary of the conclusion that the anterior-posterior pattern is established by chemotactic sorting is that the pattern can only be stably maintained in slugs if the chemotactic cell is also the principal source of the chemotactic cAMP signal. If cAMP were secreted by all cells equally or by posterior cells more than anterior cells, then the pattern in slugs would not be stable. Thus, a necessary conclusion from our results is that anterior cells are the principal source of cAMP in slug tissue. This conclusion is in agreement with several observations $[20-24,36]$.

In view of the conclusion above, one might have expected the endogenous cAMP gradient to be significantly higher in clumps containing both anterior and posterior cells than in clumps containing only posterior cells. It was therefore interesting to observe that the same exogenous cAMP concentration $\left(1 \times 10^{-7} \mathrm{M}\right)$ was required to reverse the sorting behaviour in clumps containing only posterior cells and in clumps containing anterior and posterior cells (Table 2). One possible explanation is that sorting inside or outside is controlled, not by the endogenous cAMP gradient, but by an initial local accumulation of anterior or anterior-like cells at the surface of clumps in response to exogenous cAMP. Such an accumulation would be self-reinforcing, since these cells secrete cAMP, and might dominate any endogenous cAMP gradient.

\section{Cell Type Conversion During Pattern Regeneration}

Our results indicate that the time course of pattern regeneration in isolated anteriors and posteriors is very different: anteriors require $>6 \mathrm{~h}$ to reform a prestalk-prespore staining pattern; posteriors form a staining pattern in $1.5-2 \mathrm{~h}$. These observations are similar to early observations of Raper [18] who showed that isolated anteriors fruited stalky unless they migrated for several hours, whereas isolated posteriors yielded almost normal fruiting bodies if they fruited immediately. Later, Bonner [7] showed that regeneration of the typical neutral red staining pattern was slower in anteriors than in posteriors. This difference in timing of regeneration has been assumed to be due to inherent differences in the ability of one cell type to convert to the other [33]. Our results, however, suggest that the timing difference is because anterior and posterior regeneration are, in the initial stages, two different processes. Posterior regeneration occurs by the rapid sorting out of stained anteriorlike cells from unstained posterior cells. Anteriors, by comparison, contain only one cell type and regeneration thus requires conversion of stained anterior cells into unstained posterior cells.

The conversion of prestalk to prespore cells during anterior regeneration appears to require at least $6 \mathrm{~h}$ when assayed by neutral red staining (see Results). In a similar experiment, but using prespore antibody to score the conversion of prestalk to prespore, Sakai [33] observed that 7-8 h were required for the appeareance of prespore cells. Furthermore, he showed that conversion of prespore to prestalk during regeneration of isolated posteriors also required several 
hours. (We did not observe this event in our experiments since newly differentiated prestalk cells are unstained.) While these results indicate that prestalk-prespore interconversion requires a relatively long time compared to the rapid sorting of anterior and anterior-like cells, they do not preclude the existence of more rapid differentiation events. For example, Gregg [37] observed that, within 15-30 min after isolation of the prestalk zone, some cells incorporate ${ }^{3} \mathrm{H}$-fucose in a manner typical of prespore cells. (During normal differentiation ${ }^{3} \mathrm{H}$-fucose incorporation is an early event which precedes the appearance of prespore vesicles.)

\section{Relation to Normal Morphogenesis on Agar}

To apply our results to normal development we need to understand the relationship of the pattern in submerged clumps to the anterior-posterior pattern in slugs. Our results have demonstrated that an initially random mixture of anterior and posterior cells can sort out by differential chemotaxis to form a pattern of two coherent regions of cells. Furthermore, our results show that the form of the pattern depends on specific environmental conditions. In clumps exposed to a symmetric environment in liquid suspension, the pattern is spherically symmetric: a core of anterior cells surrounded by a shell of posterior cells. The pattern appears to be due to formation of an inside-outside gradient of cAMP generated when cAMP, produced by cells in the clump, is lost by diffusion at the periphery. By comparison, in clumps exposed to a nonuniform environment such as in an asymmetric distribution of cAMP or oxygen [4], the sorting pattern is no longer spherically symmetric. The anterior cells lie at the high cAMP and high oxygen side and the posterior cells at the opposite side, reminiscent of the pattern in slugs.

During development on agar, formation of the anterior-posterior pattern occurs in a cell mass at an air-water interface. This environment clearly is asymmetric and it is not surprising, therefore, that the anterior-posterior pattern is not spherically symmetric. If cAMP is lost by diffusion into the agar, then an endogenous cAMP gradient will be established across the cell mass with its highest concentration among the cells near the surface away from the agar sink. Under these conditions we expect anterior cells to move to the top of the mass as indeed occurs. Although this mechanism appears sufficient to explain the normal pattern in aggregates, it is also possible that oxygen plays a significant role in polarizing the pattern under these conditions. We have shown elsewhere [4] that an oxygen gradient applied across a clump of slug cells embedded in agar can: (1) orient the anterior-posterior pattern with the anterior cells toward the high oxygen concentration; (2) direct the migration of such a slug-like clump up an oxygen gradient. Since a cell mass an at air-water interface is expected to experience an oxygen gradient with the highest concentration on the air side [4], it is possible that oxygen, in addition to cAMP, may contribute to the orientation of the anterior-posterior pattern during normal development. Regardless of which parameter of the air-water interface exerts a dominant influence, it is clear that the chemotactic sorting mechanism coupled with an asymmetric environment is sufficient to generate the basic polar pattern of anterior and posterior cells typical of slugs.

An interesting feature of the sorting mechanism is the localization of an extracellular signal - in this case the chemotactic agent - in one region of the slug. Such localization of a signal could be used by the organism to stimulate differentiation of cells in that region without affecting cells elsewhere in the slug. It is thus interesting to note that cAMP has already been shown to stimulate stalk cell differentiation in several situations [38-41].

While the present results indicate how the anterior-posterior pattern is formed, they do not provide information about how the proportions of prestalk and prespore cells are established. Nervertheless it is interesting to speculate on the relationship of our results to the ability of Dictyostelium to undergo proportion regulation. There is good evidence that position in the slug is the principal factor controlling the fate of cells: cells in anterior region differentiate into stalk cells; cells in posterior region differentiate into spores [13]. The present results have demonstrated that the proportion of cells entering the anterior region is controlled by the anterior region itself through its ability to inhibit anterior-like cell sorting. Thus, indirectly, by controlling the proportion of cells in the anterior region, the mechanism inhibiting chemotaxis could be involved in controlling the proportions of prestalk and prespore cells.

Acknowledgements. We thank J. T. Bonner, S. C. Kayman, H. K. MacWilliams, and C. D. Town for helpful discussions and critical reading of the manuscript. This research was supported by grants from the NIH (GM11301 and HDO 7154-01) and the NSF (77-25426). CND is recipient of a Faculty Research Award (FRA-132) from the American Cancer Society.

\section{References}

1. Williams KL, Fisher PR, MacWilliams HK, Bonner JT (1981) Cell patterning in Dictyostelium discoideum. Differentiation 18:61

2. MacWilliams H, Bonner JT (1979) The prestalk-prespore pattern in cellular slime molds. Differentiation 14:1

3. Sternfeld J, Bonner JT (1977) Cell differentiation in Dictyostelium under submerged conditions. Proc Natl Acad Sci USA 74: 268

4. Sternfeld J, David CN (1981) Oxygen gradients cause pattern orientation in Dictyostelium cell clumps. J Cell Sci 50:9

5. Sternfeld J, David CN (1979) Ammonia plus another factor are necessary for differentiation in submerged clumps of Dictyostelium. J Cell Sci 38: 181

6. Bonner JT (1947) Evidence for the formation of cell aggregates by chemotaxis in the development of the slime mold Dictyostelium discoideum. J Exp Zool 106:1

7. Bonner JT (1952) The pattern of differentiation in amoeboid slime molds. Am Nat 86: 79

8. Farnsworth PA, Wolpert L (1971) Absence of cell sorting out in the grex of the slime molds Dictyostelium discoideum. Nature 231: 329

9. Bonner JT (1959) Evidence for the sorting out of cells in the development of the cellular slime molds. Proc Natl Acad Sci USA 451: 379

10. Takeuchi I (1963) Immunochemical and immunohistochemical studies on the development of the cellular slime mold Dictyostelium mucoroides. Dev Biol 8:1

11. Takeuchi I (1965) Establishment of polar organization during slime mold development. In: Cowdry EV, Seno S (eds) Nucleic acid metabolism, cell differentiation, and cancer growth. Pergamon Press, Oxford

12. Bonner JT, Sieja TW, Hall EM (1971) Further evidence for the sorting out of cells in the differentiation of the cellular slime mould Dictyostelium discoideum. J Embryol Exp Morphol 25: 457

13. Leach CK, Ashworth JM, Garrod DR (1973) Cell sorting out during the differentiation of mixtures of metabolically distinct populations of Dictyostelium discoideum. J Embryol Exp Morphol 29: 647 
14. Maeda Y, Maeda M (1974) Heterogeneity of the cell population of the cellular slime mold Dictyostelium discoideum before aggregation and its relation to the subsequent location of the cells. Exp Cell Res 84: 88

15. Matsukuma S, Durston AJ (1979) Chemotactic cell sorting in Dictyostelium discoideum. J Embryol Exp Morphol 50:243

16. Tasaka M, Takeuchi I (1979) Sorting out behavior of disaggregated cells in the absence of morphogenesis in Dictyostelium discoideum. J Embryol Exp Morphol 49:89

17. Nestle M, Sussman M (1972) The effect of cyclic AMP on morphogenesis and enzyme accumulation in Dictyostelium discoideum. Dev Biol 28:545

18. Raper KB (1940) Pseudoplasmodium formation and organization in Dictyostelium discoideum. J Elisha Mitchell Sci Soc 56: 633

19. Wartiovaara J, Nordling S, Lehtonene E, Saxen L (1974) Transfilter induction of kidney tubules; correlation with cytoplasmic penetration into Nucleopore filters. J Embryol Exp Morphol 31: 667

20. Bonner JT (1949) The demonstration of acrasin in the later stages of the development of the slime mold Dictyostelium discoideum. Biol Bull 99: 143

21. Pan P, Bonner JT, Wedner HJ, Parker CW (1974) Immunofluorescence evidence for the distribution of cyclic AMP in cells and cell masses of the cellular slime molds. Proc Natl Acad Sci USA $71: 1623$

22. Rubin J (1976) The signal from fruiting body and conus tips of Dictyostelium discoideum. J Embryol Exp Morphol 36:261

23. Town CD, Stanford E (1977) Stalk cell differentiation by cells from migrating slugs of Dictyostelium discoideum: special properties of tip cells. J Embryol Exp Morphol 42:105

24. Brenner M (1977) Cyclic AMP gradients in migrating pseudoplasmodia of the cellular slime mold Dictyostelium discoideum. J Biol Chem 252: 4073

25. Bulychev A, Trouet A, Tulkens $P$ (1978) Uptake and intracellular distribution of neutral red in cultured fibroblasts. Exp Cell Res 115: 343

26. Quiviger B, Benichou J-C, Ryter A (1980) Comparative cytochemical localization of alkaline and acid phosphatases during starvation and differentiation of Dictyostelium discoideum. Biol Cellulaire 37:241

27. Maeda Y, Takeuchi I (1969) Cell differentiation and fine structures in the development of the cellular slime molds. Dev Growth Differ 11:232
28. Hohl HR, Hammamoto ST (1969) Ultrastructure of spore differentiation in Dictyostelium: the prespore vacuole. J Ultrastruct Res 26: 442

29. Gregg JA, Badman WS (1970) Morphogenesis and ultrastructure in Dictyostelium. Dev Biol 22:96

30. Ikeda T, Takeuchi I (1971) Isolation and characterization of a prespore specific structure of the cellular slime mold Dictyostelium discoideum. Dev Growth Differ 13: 221

31. Mueller U, Hohl HR (1973) Pattern formation in Dictyostelium discoideum: temporal and spatial distribution of prespore vacuoles. Differentiation 1:267

32. Farnsworth P, Loomis WF (1976) Quantitation of the spatial distribution of 'prespore vacuoles' in pseudoplasmodia of Dictyostelium discoideum. J Embryol Exp Morphol 35: 499

33. Sakai Y (1973) Cell type conversion in isolated prestalk and prespore fragments of the cellular slime mold Dictyostelium discoideum. Dev Growth Differ 15: 11

34. Bonner JT (1957) A theory of the control of differentiation in the cellular slime molds. Q Rev Biol 32:232

35. Sampson J (1976) Cell patterning in migrating slugs of Dictyostelium discoideum. J Embryol Exp Morphol 36:663

36. Rubin J, Robertson A (1975) The tip of the Dictyostelium discoideum pseudoplasmodium as an organizer. J Embryol Exp Morphol 33: 227

37. Gregg JH, Karp GC (1978) Patterns of cell differentiation revealed by $\mathrm{L}-\left[{ }^{3} \mathrm{H}\right]$ fucose incorporation in Dictyostelium. Exp Cell Res 112: 31

38. Bonner JT (1970) Induction of stalk cell differentiation by cyclic AMP in the cellular slime mold Dictyostelium discoideum. Proc Natl Acad Sci USA 65: 110

39. Chia WK (1975) Induction of stalk cell differentiation by cyclic AMP in a susceptible variant of Dictyostelium discoideum. Dev Biol 44: 239

40. Town CD, Gross JD, Kay RR (1976) Cell differentiation without morphogenesis in Dictyostelium discoideum. Nature 262:717

41. Francis D, Salmon D, Moore B (1978) A mutant strain of Polyspondylium pallidum deficient in production of cyclic AMP. Dev Biol 67: 232

Received and accepted April 1981 